\title{
Hong Kong's Banking Industry Facing Keen Competition
}

With special reference to the opportunities open to the banks after China's entry to the WTO

\section{Peter Chiu}

\section{(2) OpenEdition}

\section{Journals}

Electronic version

URL: http://journals.openedition.org/chinaperspectives/260

DOI: $10.4000 /$ chinaperspectives. 260

ISSN: 1996-4617

\section{Publisher}

Centre d'étude français sur la Chine contemporaine

\section{Printed version}

Date of publication: 15 April 2003

ISSN: 2070-3449

\section{Electronic reference}

Peter Chiu, « Hong Kong's Banking Industry Facing Keen Competition », China Perspectives [Online], 46 | march-april 2003, Online since 29 August 2006, connection on 28 October 2019. URL : http:// journals.openedition.org/chinaperspectives/260 ; DOI : 10.4000/chinaperspectives.260

This text was automatically generated on 28 October 2019

(c) All rights reserved 


\section{Hong Kong's Banking Industry Facing Keen Competition}

With special reference to the opportunities open to the banks after China's entry to the WTO

\section{Peter Chiu}

1 In Hong Kong, the development of the banking system is an important aspect of its economic development. Government statistics show that at the end of December 2002 there were 133 licensed banks, 46 restricted banks, and 45 deposit-taking companies in Hong Kong. Most of the major foreign banks have branches in Hong Kong. All of the above have made Hong Kong the international financial centre that it is, and today flourishing in the field of offshore banking. Moreover, since 1979 when China first began to open its economy, banks in Hong Kong have provided finance to many China development projects ${ }^{1}$.

2 There is no central bank in Hong Kong. The Hong Kong Monetary Authority (HKMA), set up in 1995, performs most of the functions of a central bank, except for the issue of banknotes, which function is entrusted to three commercial banks, namely, the Hongkong \& Shanghai Banking Corporation (a British bank), the Standard Chartered Bank (a British bank) and the Bank of China. The HKMA is the authority for the regulation of the banking industry. It is also a lender of last resort to the commercial banks. One major function of the HKMA is to operate the linked rate system, which Hong Kong adopted in October 1983, and under which the HK dollar is linked to the US dollar at the rate of US\$1:HK\$7.8. The linked rate system is considered to be the corner stone of Hong Kong's economic and financial stability and the government is determined to maintain it ${ }^{2}$.

3 The deposit-taking companies appeared in the early seventies. Their number increased rapidly and the Deposit-Taking Company Ordinance was passed in 1976 requiring such companies to be registered under the ordinance and be governed by it. Initially two types of financial institution, very different in nature, were required to register as deposit-taking companies, 1) "finance companies", which received deposits and engaged in businesses such as hire-purchase financing, stock financing and personal 
loans; and 2) "merchant banks", representative offices of overseas banks which registered as deposit-taking companies because no banking licences were granted during the period 1964-1978. These merchant banks engaged in businesses such as corporate finance, financial consultancy and investment management. They were later granted the title "Restricted Banks". Thus, Hong Kong's banking system is a three-tier system consisting of the licensed banks, restricted banks and deposit-taking companies 3 .

4 From July 1964 to July 2001 the Interest Rate Agreement (IRA), a cartel type agreement between the banks, was in force and required licensed banks to observe the Interest Rate Rules of the IRA. The purpose of setting up the IRA in 1964 was to maintain orderly business operations within the banking industry. While the IRA does not apply to deposit-taking companies or restricted banks as their business differs from that of the licensed banks, they are subject to stricter rules on receiving deposits from the public. The IRA, considered to be a hindrance to competition and efficiency, was abolished in July 2001. Its abolishment has resulted in keen competition between the banks in Hong Kong. There have been winners and losers as a result of this major change.

China's entry to the WTO has tremendous implications for Hong Kong. With China's opening up in 1979, a process of economic integration between Hong Kong and mainland China began. Hong Kong benefited from the investment opportunities in China, acting as an entrepôt between China and the West, and the provision of commercial and financial services to the mainland. Now that China has gained entry to WTO, it is expected that Hong Kong can play a more important role in China's economic development ${ }^{4}$.

A condition of membership is that China should open up its banking industry to foreign banks. Foreign banks, including Hong Kong's banks, can now operate in China, albeit with conditions and restrictions. However, these conditions and restrictions will be relaxed gradually until the foreign banks are free to do business in all parts of China. This has provided the Hong Kong banks with new opportunities to expand into the mainland.

7 This article will examine the banking environment in Hong Kong following the Asian financial crisis, and especially after interest rates deregulation in July 2001. The opportunities for Hong Kong's banks after China's entry to the WTO are also analysed.

Hong Kong's banking environment after the Asian financial crisis

8 The Asian financial crisis left many Asian countries' banking systems in ruins. The sudden massive outflow of money from the Asian region was disastrous for these fragile structures. They were poorly managed and lacked proper supervision and regulation. Banks in these countries granted excessive loans to risky projects such as property, stocks and unsecured personal loans. When the Asian financial crisis took place resulting in drastic falls in the prices of property and stocks, borrowers were unable to repay their debts, and banks found themselves facing crushing financial difficulties.

Banks in Hong Kong escaped disaster; mainly because the industry is well regulated and the banks themselves are financially sound, e.g., they are not allowed to hold more than $40 \%$ of their assets in property related assets; they can only finance mortgage borrowers for $70 \%$ of their mortgage loans; and they normally hold a capital adequacy ratio of $18 \%$, much higher than the international requirement of $12 \%$. 
10 Although banks in Hong Kong are financially sound, they had a hard time during the Asian financial crisis and thereafter. The drastic fall in the demand for loans has led to great falls in their profits. Many banks have had to cut back on their expenses, downsizing as a result, needing to find new sources of income other than from lending. Many have expanded into insurance, stock brokerage, bond finance, etc.

Table 1: Loans and advances by type of authorised institutions (HKD billion)

\begin{tabular}{|c|c|c|c|c|c|}
\hline Year & 1997 & 1998 & 1999 & 2000 & 2001 \\
\hline $\begin{array}{l}\text { To finance imports } \\
\text { to and exports from } \\
\text { Hong Kong }\end{array}$ & 172 & 132 & 102 & 93 & 80 \\
\hline $\begin{array}{l}\text { To finance } \\
\text { merchandising trade } \\
\text { not touching } \\
\text { Hong Kong }\end{array}$ & 20 & 16 & 10 & 10 & 7 \\
\hline $\begin{array}{l}\text { Other loans for use } \\
\text { in Hong Kong }\end{array}$ & 2,037 & 1,960 & 1,819 & 1,861 & 1.791 \\
\hline $\begin{array}{l}\text { Other loans for use } \\
\text { outside Hong Kong }\end{array}$ & 1,843 & 1,167 & 857 & 477 & 295 \\
\hline $\begin{array}{l}\text { Other loans where } \\
\text { the place of use is } \\
\text { not known }\end{array}$ & 47 & 27 & 22 & 18 & 9 \\
\hline $\begin{array}{l}\text { Total loans } \\
\text { and advance }\end{array}$ & 4,121 & 3,304 & 2,812 & 2,461 & 2,185 \\
\hline
\end{tabular}

Source: Table 2.4, Monthly Statistical Bulletin, Hong Kong Monetary Authority, Hong Kong government, mai 2002.

11 Table 1 shows the loans and advances by type by authorised institutions in Hong Kong. All types of loans have fallen drastically since 1997. The total amount of loans in 2001 was just about half of the total in 1997. The item "Other loans for use outside Hong Kong" dropped from HK\$1,843 billion in 1997 to HK\$295 billion in 2001, revealing a drastic fall in offshore lending. The item "Finance to merchandising trade not touching Hong Kong" refers to banks providing finance to Hong Kong businessmen to export their goods produced in mainland China directly from mainland Chinese ports. A kind of offshore lending by nature, this has also fallen drastically since 1997. There has also been a fall in the item "Other loans for use in Hong Kong", which explains the slowing down of lending within Hong Kong.

Table 2 shows the external liabilities and claims of Hong Kong banks vis-à-vis major countries from 1997 to 2001. Two points are worth noting. First, the liabilities to banks outside Hong Kong in US dollars dropped significantly from 3,726 billion in 1997 to 1,313 billion in 2001. This reveals that foreign banks have withdrawn substantial amounts of money from banks in Hong Kong. This is a clear consequence of the Asian financial crisis when there was huge capital outflow. Second, the claims on non-bank customers outside Hong Kong in US dollars also saw a huge fall from 2,049 billion in 1997 to 579 billion in 2001. This implies that banks in Hong Kong have reduced their offshore lending considerably, which reinforces the findings from Table 1.

13 Table 3 shows the principal statistics for all banks in Hong Kong from 1996 to 2000 (Figures for 2001 are not yet available). Several points are worth noting. First, the 
number of banks has fallen from 186 in 1996 to 158 in 2000. This is mainly due to the retreat of some Japanese banks after the Asian financial crisis (The number of banks had increased again to 179 by the end of 2002). Second, syndication of loans dropped considerably in 1998 and 1999, but increased again in 2000. This is due to increased domestic lending to companies following a short-lived economic recovery in 2000 (See Table 4). Third, there is a large increase in "dividends received and profit from trading in securities" in 1999, due mainly to the rebound in share prices in 1999 after price collapses in 1998 during the Asian financial crisis.

14 Table 4 shows the GDP growth, unemployment rate and inflation rate of Hong Kong in the past years. These indicators unanimously point to the slowing down of the economy after the Asian financial crisis, with adverse effects on the business of the banks. After a short-lived recovery in 1999 and 2000, GDP again slowed in 2001 and 2002. Unemployment increased to $7 \%$ in 2002. Deflation has been prolonged for four years so far. The slowing down of the Hong Kong economy is due mainly to the adverse economic situation worldwide after September 11th, structural change and sluggish consumption within Hong Kong.

The above analysis reveals that banks in Hong Kong faced a difficult time after the Asian financial crisis, with a fall in loans both in the domestic market and offshore markets. Competition for business was certainly keen. It was under these conditions that the deregulation of the IRR took place, which made competition keener.

Deregulation of the IRR

16 July 3rd 2001 was an important date in the development of Hong Kong's banking industry. On that day the Interest Rate Agreement (IRA) of the HKAB was abolished. Banks in Hong Kong now set their interest rates on deposits and loans. Prior to deregulation, banks had to observe a uniform lending rate, called the prime rate, and a set of uniform deposit rates.

Table 2: External liabilities and claims of banks in Hong Kong (Positions vis-à-vis major countries, HKD billion)

\begin{tabular}{llrrrrr|}
\hline Year & & 1997 & 1998 & 1999 & 2000 & 2001 \\
\hline Liabilities to banks & HK\$ & 296 & 238 & 185 & 231 & 175 \\
outside Hong Kong & US\$ & 3,726 & 2,606 & 2,048 & 1,588 & 1,313 \\
\hline Claims on banks & HK\$ & 205 & 175 & 173 & 201 & 169 \\
outside Hong Kong & USS & 2,337 & 2,292 & 2,409 & 2,535 & 2,320 \\
\hline Liabilities to non-bank & HK\$ & 51 & 55 & 65 & 80 & 77 \\
customers outside HK & USS & 552 & 565 & 589 & 616 & 495 \\
\hline Claims on non-bank & HKS & 60 & 73 & 75 & 90 & 90 \\
customers outside HK & USS & 2,049 & 1,340 & 1,038 & 684 & 579 \\
\hline
\end{tabular}

Source: Table 2.9, Monthly Statistical Bulletin, Hong Kong Monetary Authority, May 2002.

Under the IRA a cartel-type interest rate arrangement was practiced for more than three decades. The arrangement was initially regarded as necessary for maintaining banking stability. However, the arrangement gradually became an obstacle for competition and efficiency. The result was that the depositors and the borrowers were being exploited. The depositors obtained excessively low deposit rates from the banks, and the borrowers had to pay excessively high lending rates for their loans. 
18 Although the IRA contributed to banking stability by maintaining orderly banking operations within the banking system, it was increasingly felt that the cartel-type arrangement seriously handicapped competition. Inefficient banks and efficient banks operated under the same interest rate rules. Efficient banks were not allowed to offer higher deposit rates to bid for deposits, nor could they offer loans at rates lower than the prime rate.

19 It was also found that the wide spread between the lending rates and the deposit rates resulted in large profit margins for the banks. This could not have occurred but for the monopoly power of the HKAB in setting interest rates. Professor KY Chan, who was appointed by the government as the president of the Consumer Council, was most active in requesting the government for the abolishment of the IRA. Professor Chan pointed out that the cartel-type IRA impeded competition and enabled the banks to reap gigantic profits, exploiting depositors and borrowers.

20 Professor Chan's proposal to abolish the IRA was accepted by the government, in spite of strong objections from the banks. It was abolished in stages. In the first stage, effective from July 1999, interest rates on deposits longer than seven days were deregulated. In the second stage, effective from July 2000, interest rates on deposits of less than seven days were deregulated. In the last stage, effective from 3 July 2001, interest rates on all deposits were completely deregulated.

21 As to lending rates, deregulation in fact started from July 2000, a year ahead of complete interest rate deregulation. Banks began to offer lending rates lower than the prime rate set by the HKAB. At first a lending rate $1 \%$ lower than prime rate was offered by banks to compete for mortgages. Gradually competition resulted in the mortgage rate dropping to $2.5 \%$ below the prime rate. For mortgage borrowers it was astonishing. Accompanied by a continuously dropping prime rate as a result of the link with US interest rates under the linked exchange rate system, mortgage rates dropped further. Compared with the mortgage rates charged by the banks several years ago, mortgage rates are considerably lower.

Following complete deregulation of the IRR on July 3rd 2001 banks each announced their own prime rate. As to deposit rates, each bank declared a "basic saving deposit rate (BSDR)" to which its deposit rates would be linked. Deposits of larger amounts would enjoy a deposit rate higher than the BSDR and deposits of smaller amounts would have a deposit rate lower than the BSDR. Some banks even declared not to offer any interest rate for small amounts of deposits such as deposits of less than HK\$5,000. Table 5 shows the deposit rate offered by the Hongkong \& Shanghai Banking Corporation.

23 Smaller banks decided to offer deposit rates higher than those offered by the Hongkong \& Shanghai Banking Corporation in order to bid for deposits. For example, a local Chinese bank, Wing Lung Bank, offered the deposit rates as shown in Table 6 below.

Prime rates and basic savings rates in turn are set by reference to interbank rates. Under the linked rate system, when interest rates in the USA are reduced, money will flow into HK dollars. The increased liquidity in the money markets will exert downward pressure on interbank rates. As interbank rates reflect the market levels of interest rates and the costs of funds for banks, banks will set their prime rates and basic savings deposit rates by reference to the interbank rates. 
There was no sudden shock for the banking system upon the complete deregulation of the IRA. Deregulation had in fact started long before July 3rd 2001, the banks and the public were well prepared for the event. However the event represented an important milestone in the development of banking in Hong Kong. Competition would certainly become keener among the banks thereafter. But with it would come enhanced efficiency and benefits for depositors and borrowers.

Who are the winners in the deregulation? Obviously the mortgage borrowers are the first among the winners. Before deregulation, mortgage borrowers had to borrow normally at interest rates $1 \%$ higher than the prime rate. After deregulation, they were able to borrow at interest rates $2.5 \%$ below the prime rate. The difference is $3.5 \%$. Assume that a person borrows HK\$1 million from a bank for a mortgage, the saving in interest per annum amounts to $\mathrm{HK} \$ 35,000$.

Other types of borrowers such as commercial and industrial firms also benefit, although to a lesser extent. Without the restriction of the prime rate rule, banks can now lend money to these firms at lower rates than previously. However, it must be pointed out that after the Asian financial crisis, banks have become very cautious when lending to the commercial and the industrial sectors. Unless they can prove that they have the potential to make profits, the banks are reluctant to provide them loans.

Table 3: Prinicipal statistics for banks in Hong Kong (HKD billion)

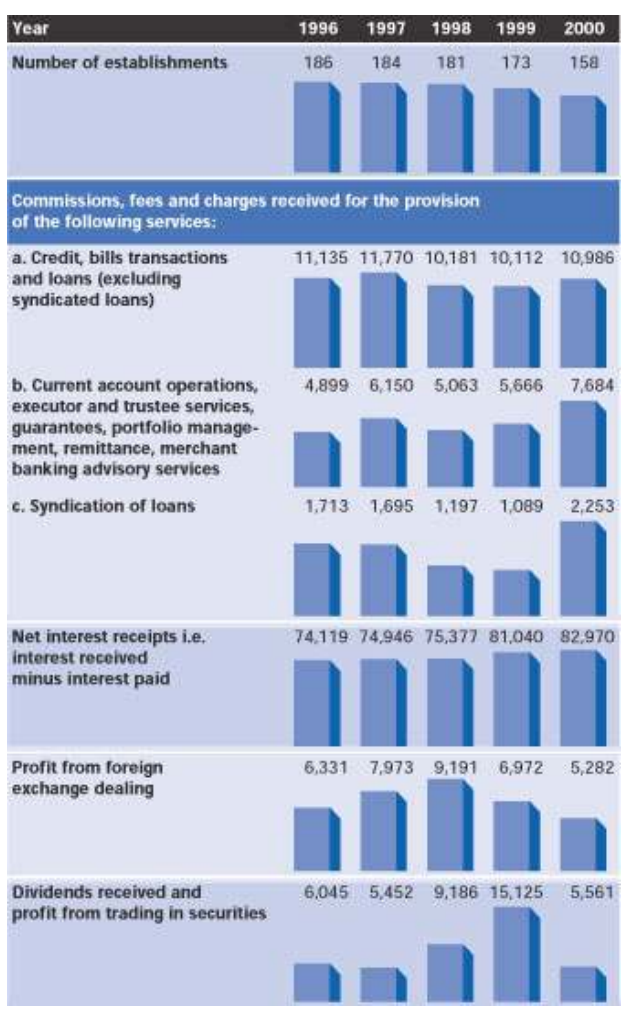

Source: Table 5.12, 'Principal Statistics for licensed Banks in Hong Kong', Hong Kong annual Digest of Statistics, Census and Statistics Department, Hong Kong Government, 2002.

Property developers are also among the winners. The reduction in mortgage interest rates has resulted in increased demand for properties. This has helped to halt the falling property prices following the Asian financial crisis. At present property prices are just $40 \%$ of their peak levels in 1997 . The increased demand for properties has 
prevented prices continuing to fall. However, there is still no sign that property prices will rise in the near future, as economic growth remains slow and deflation persists.

Competition among the banks has resulted in new methods of finance provided to mortgage borrowers. Some banks are now offering "cash rebates" up to $8 \%$ of the loans to the mortgage borrowers. Property developers also compete for buyers with new methods of payment terms. Some have set up their own subsidiary finance companies to provide second mortgages to their buyers up to $25 \%$ of the purchase price (banks can only provide $70 \%$ of the purchase price in a first mortgage). Some even offer such favourable terms as to waive the interest and principal of the second mortgage for the first two years. This provides liquidity to property buyers in the early years of becoming property owners. The term "Zero Downpayment" has emerged. This is because the bank provides $70 \%$ first mortgage and grants up to $8 \%$ cash rebate of the mortgage loan (equivalent to $5 \%$ of the purchase price) while the property developer provides a $25 \%$ second mortgage, which totals $100 \%$ of the purchase price. So no initial downpayment is needed.

In spite of the favourable terms offered by banks and property developers, potential buyers certainly will consider their ability to pay. This is affected by their view of the security of their jobs and the future trend of interest rates. As the economy is still stagnant, with the unemployment rate staying high, confidence has not yet recovered. Those who buy properties for investment, i.e. for renting, will consider the risk of falling rents along with greater supply of flats in the rental market.

The Mortgage Corporation, which was set up by the government several years ago to provide additional loans (up to 90\%) to mortgage borrowers above the $70 \%$ of the property value permitted to banks, has increased the loan amount to $140 \%$ of the property value. This facility is to provide assistance to those who have bought properties at peak prices in 1997 and have now become the owners of "negative asset" properties. By restructuring their loans with the $140 \%$ finance, these owners of "negative asset" properties can enjoy the lower interest rates provided by banks now. However these property owners have to cover insurance by paying a lump sum insurance premium to the Mortgage Corporation for the part of the mortgage loan in excess of $70 \%$.

In the latest development, the HKMA has allowed banks to offer mortgage loans of up to $90 \%$, but must also cover insurance for the $20 \%$ in excess of the $70 \%$ permitted to them. This is the "one station mortgage", as the borrower only needs to file one application to the bank. (Previously the mortgage borrower had to file an application to the bank for the $70 \%$ mortgage and another application to the Mortgage Corporation for the extra 20\%). This new measure is aimed at simplifying the application procedure thereby providing the borrower greater convenience when applying for a mortgage.

Keen competition among banks for mortgage lending has resulted in smaller profit margins for the banks. As banks are mostly awash with deposits and facing low demand for loans from industry, mortgages provide them an outlet for their funds. Also the default rate is comparatively low being only $1 \%$ on average over time. The low risk is the result of the restriction imposed by the HKMA that mortgage borrowers' monthly repayments should not exceed $50 \%$ of their monthly income. 
Table 4: Real growth rate, unemployment rate and inflation rate

\begin{tabular}{|l|c|c|c|}
\hline Year & $\begin{array}{c}\text { Real growth rate } \\
(\%)\end{array}$ & $\begin{array}{c}\text { Unemployment rate } \\
(\%)\end{array}$ & $\begin{array}{c}\text { Inflation rate } \\
(\%)\end{array}$ \\
\hline 1995 & 3.9 & 3.2 & 8.7 \\
\hline 1996 & 4.5 & 2.8 \\
\hline 1997 & 5.1 & 2.2 \\
\hline 1998 & -5.1 & 4.7 \\
1999 & 3.4 & 6.2 \\
\hline 2000 & 10.2 & 4.9 \\
\hline 2001 & 0.6 & 5.1 \\
\hline 2002 & $1.0^{*}$ & $7.0^{*}$ \\
\hline
\end{tabular}

Source: Hong Kong Monetary Authority.

Who then are the losers of interest rate deregulation? The small depositors. Banks are now more concerned about their funding costs. One way to reduce theses costs is to reduce interest rates paid to small depositors. Some banks have even imposed charges for deposits smaller than HK\$1,000. This has naturally led to complaints. Many people protest that banks are discriminating against poor people, as small depositors are normally the elderly or economically weak. Social activists have criticised banks for not taking their social responsibility to take care of these people. Most elderly people receive old age subsidies from the government through their saving accounts in banks. Those who obtain social welfare subsidies from the government also are drawing their money through their saving accounts. In response to these criticisms most banks have announced a waiver on the charges on small deposits for these categories of depositors.

As a whole, deregulation of the IRR was an unavoidable development. The view of the HKMA is that deregulation is the right way to go. While the IRR did serve a useful stabilising function in the past, they became increasingly outdated in a mature banking system like Hong Kong's. They imposed a rigidity and inefficiencies in the setting of deposit rates and lending rates and inhibited the development of new banking products 5 .

However the HKMA is also concerned about consumer protection. As mentioned above, deregulation of interest rates is likely to lead to increases in fees and charges for banking services. While the HKMA does not regulate fees and charges, it has a strong interest in ensuring that the pricing structure of banks is transparent and that customers are given sufficient notice of any fee adjustments. The HKMA also considers that, while banks are free to determine their charging policy, they should be sensitive to the impact of increases in charges on small account holders and the disproportionate effect that such charges can have on the more vulnerable members of the communities. Advises on this matter has been given by the HKMA to the banks which have subsequently introduced various privileged measures for elderly people receiving old age subsidies, and those who obtain social welfare subsidies, through their saving accounts ${ }^{6}$.

Strategies adopted amid keen competition

Strategies have been adopted by banks to beat the competition developing within the banking system, including increasing their share in the mortgage market, promotion campaigns and special counters in branches for the promotion of mortgage business. Some banks offer telephone enquiry services for mortgage facilities operating even on 
Saturday and Sunday. As mentioned earlier, banks are now providing cash rebates to mortgage borrowers.

As interest-earning business is becoming more difficult, banks are increasingly relying on non-interest earning business, such as insurance, provident fund business, stock transactions, sale of bonds, etc. These types of business are not traditionally the business of banks in Hong Kong. However they have in the past few years stepped into these businesses to widen their sources of income. Banks in other countries, however, took this step much earlier.

The law provides that from December 2000 all employers should provide a mandatory provident fund (MPF) scheme for their employees. The law gives the insurance companies and the banks the right to market provident fund products and collect fund contributions from their clients. The moneys are then entrusted to the merchant banks for investment and provision of pensions. The practice is new in Hong Kong and has provided the banks with new business.

Table 5: Deposit rates offered by the HSBC, July $3^{\text {rd }} 2001$.

\begin{tabular}{|c|c|}
\hline Amount of Deposits & $\begin{array}{l}\text { Hongkong Shanghai Bank Saving Rate: } \\
(1.75 \%)\end{array}$ \\
\hline$\$ 150,000$ or above & Saving Rate $+0.25 \%$ \\
\hline$\$ 10,000-\$ 149,999$ & Saving Rate, Le. $1.75 \%$ \\
\hline$\$ 5,000-\$ 9,999$ & Saving Rate - $1 \%$ \\
\hline$\$ 1000-\$ 4,999$ & $\begin{array}{l}\text { Saving Rate }-2.5 \% \text { or } 1 \% \\
\text { which ever is lower }\end{array}$ \\
\hline$\$ 999$ or lower & $0 \%$ \\
\hline
\end{tabular}

Source: Xinbao, July $4^{\text {th }} 2001$.

Table 6: Deposit rates offered by the Wing Lung Bank, July $3^{\text {rd }} 2001$

\begin{tabular}{ll|} 
Amount of deposits & Wing Lung Bank Saving Rate: \\
& $1.75 \%$
\end{tabular}

Source: Xinbao, July $4^{\text {th }} 2001$

Recently banks have found themselves involved in another new business, namely, the sale of bonds for large corporations such as the Mortgage Corporation and the Mass Transit Railway. As banks have large branch networks their networks are considered ideal channels for selling these bonds. Bonds used to be issued through the merchant banks, but are now issued in smaller denominations and the banks have in effect become bond retailers.

41 The emphasis on diversifying into non-interest earning businesses means greater demand for expertise among bank staff. Bank staff are now required to study the MPF rules and to attend examinations to obtain licences from the government. The law provides that no-one without a licence can deal in MPF. To be able to deal in insurance products and bonds, bank staff must also learn about investment and related sales procedures. To be able to deal in stocks they need to acquire knowledge about shares 
and the rules of stock operations. As a whole, as competition between banks increases so does the pressure on bank staff.

42 Consolidation and mergers have increased. Local Chinese banks in Hong Kong are traditionally resistant to consolidation and merger. Many of these banks are family businesses and have tried to maintain family control. However as competition becomes increasingly keen the limited resources of the family may not be sufficient to introduce the technical innovations needed to stand against competition. At the same time some foreign banks need business partners in order to expand into Hong Kong. Now that China has gained entry to the WTO, having a banking base in Hong Kong for the foreign banks is a stepping-stone to doing banking business in China. Recently the Development Bank of Singapore made a successful bid to take over the Dao Hang Bank, a local Chinese bank. It is expected that some local Chinese banks will be taken over by other foreign banks in the future. The HKMA has also encouraged banks to merge in order to benefit from economies of scale ${ }^{\text {? }}$.

Table 7 : Major balance sheet items by country/region of ownership of authorised institutions (HKD billion)

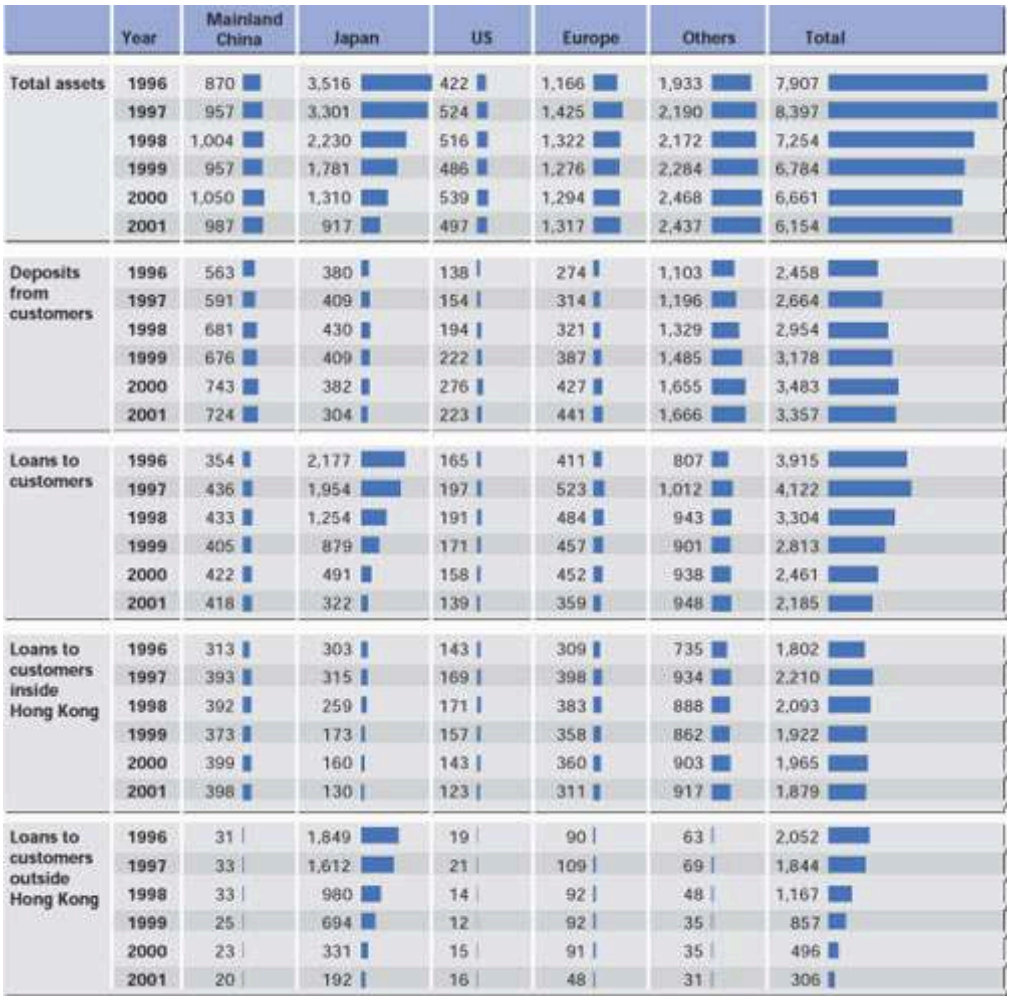

Source: Table G, Annual Report 2001, Hong Kong Monetary Authority.

43 In order to maintain its market share and to benefit from economies of scale the group of twelve mainland Chinese banks with the Bank of China at their head introduced restructuring and merged with the Bank of China. The restructuring was completed at the end of 2001. Other examples are the merger of the Kong On Bank (a local Chinese Bank) with the Singapore Overseas Trust Bank and the merger of the First Pacific Bank (a local Chinese bank) with the Bank of East Asia (a leading local Chinese bank).

Banks are making efforts to increase their ability to master new technology available for raising efficiency, especially e-banking. By the end of 2001 over twenty banks and 
banking groups in Hong Kong have introduced Internet banking services. To ensure proper supervision of this aspect of banking development, in May 2001 the HKMA issued the "Guidelines on Authorisation of Virtual Banks", aimed at banks that deliver banking services wholly or primarily using the Internet or other electronic delivery channels. It operates on the principle that the HKMA will permit the establishment of virtual banks in Hong Kong provided they can satisfy the same prudential criteria that apply to conventional banks ${ }^{8}$.

Another area of competition is credit card business, a traditional business of the banks. Keen competition has occurred in this area with the result that banks have become less cautious in issuing credit cards and granting credit facilities. Credit card bad debts have increased rapidly. According to the statistics released by the HKMA, credit card default rates reached $12.8 \%$ in the first quarter of 2002 , and as banks have engaged debtcollecting companies, complaints have increased with regard to the ensuing debtcollection practices. HKMA statistics also show that in the first half of 2002 there were 479 complaints and nearly half were related to the debt-collection practices of these companies. Notice has been given by the HKMA to the banks requiring them to improve their relationship with debtors and the debt-collecting companies. Banks are also required respond to these complaints by the end of each quarter ${ }^{9}$.

Competition results in changing market share over time. Table 7 shows the major balance sheet items by country/region of ownership of all banks in Hong Kong from 1996 to 2001. It can be seen that mainland Chinese banks (merged with the Bank of China at end of 2001) now occupy the largest market share in terms of deposits and loans-a result of rapid expansion of banking activities by mainland banks in Hong Kong. In contrast, Japanese banks have considerably reduced their lending activities in Hong Kong. US banks maintain a significant and steadily growing market share, and the market share of the European banks as a group is also substantial with steady growth in deposits in Hong Kong. It is worth noting that the market share of local Chinese banks is not listed due perhaps to their insignificant market share.

Opportunities open to banks in Hong Kong after China's entry to the WTO

China gained entry to the WTO at the end of 2001. The World Bank's recent estimates give an indication of the growth potential of China's trade as a result-China's share in world trade will double within the next five years and its share of world exports is expected to increase from the present $3.7 \%$ to around $7.3 \%$ by 2005 . China's share in world imports is expected to rise from the present $3.4 \%$ to $7 \%$ within the next five years.

China's accession also has great implications for Hong Kong's banking sector. According to the framework of the WTO agreement, the entry requirement for the banking sector is much broader and the reforms more profound. These not only provide overseas banks with tremendous opportunities, but should also galvanise China's banking sector into operating in line with the international standards.

The direction of reform has been established, which is to allow more market forces to direct banking development. Market operation implies competition and it is expected that banks in China will have a hard time competing among themselves and with the foreign banks including the Hong Kong banks that will be set up there.

50 As to the effect of China's accession on Hong Kong's banking business, Joseph Yam, the Chief Executive of the HKMA, highlighted the "the creation effect" and "the diversion effect". The creation effect of WTO entry will result in a surge in banking business on 
the mainland. There are two main elements in this process. The first is a greater demand for banking services, resulting from the growth induced by the effects of WTO accession. The second is the financial deepening stimulated by more rapid financial liberalisation, greater banking competition, and product innovation induced by the terms of WTO accession. These processes have positive implications for domestic banks incorporated in the mainland and for foreign banks, including Hong Kong banks ${ }^{10}$.

Table 8: An analytical framework of opportunities

\begin{tabular}{ccccc|}
$\begin{array}{l}\text { Number of } \\
\text { variables }\end{array}$ & $\begin{array}{c}\text { Currency } \\
\text { denomination }\end{array}$ & Location & $\begin{array}{c}\text { Intermediation } \\
\text { channel }\end{array}$ & $\begin{array}{c}\text { Customers } \\
\text { served }\end{array}$ \\
\hline 2 & Foreign & Mainland & Debt & $\begin{array}{r}\text { Resident: } \\
\text { Individuals } \\
\text { Resident: } \\
\text { Companies }\end{array}$ \\
3 & N.A. & N.A. & Equity & $\begin{array}{r}\text { Non-resident: } \\
\text { Individuals }\end{array}$ \\
4 & N.A. & N.A. & N.A. & $\begin{array}{c}\text { Non-resident: } \\
\text { Companies }\end{array}$ \\
\hline
\end{tabular}

Source: Table 1 in 'Understanding Mainland Reform', Hong Kong Government Press Release, May $17^{\text {th }}$ 2001.

However, beside the creative effect there is also the diversion effect. According to Joseph Yam, it is quite natural that foreign banks will find it attractive to deal directly with the mainland, rather than through Hong Kong. But there should still be factors that encourage them to continue to use Hong Kong as a base. For example, given economies of scale, it is much cheaper for foreign banks to cover their China operations through their Hong Kong offices, rather than incurring the additional costs of setting up a new office in, say, Shanghai. Corporate tax in Shanghai is also twice what it is in Hong Kong. Other positive inducements include the efficiency and sophistication of Hong Kong's financial markets, the well-regulated financial system, etc. According to Joseph Yam, studies carried out by the HKMA have found that the creation effect outweighs the diversion effect. Hong Kong's banking sector stands to benefit substantially from the increased demand for banking services in China. This will boost Hong Kong's lending business to China, provided that Hong Kong can continue to improve its infrastructure framework and its regulatory regime so that the diversion effect is minimised ${ }^{11}$.

The HKMA has developed a comprehensive analytical framework that may enable opportunities to be identified systematically and assessed realistically. The framework is set out in Table 8 . There are altogether 48 ( 2 by 2 by 3 by 4 ) combinations of the four headings of characteristics, representing 48 ways of doing business. For example, we can ask ourselves what roles Hong Kong can play, if any, in renminbi banking business on the mainland targeted at resident individuals. Another combination may be foreign currency equity business in the mainland targeted at non-residents. Such are the many banking business opportunities for Hong Kong banks in China ${ }^{12}$. their advantage. Recently, Dai Xianglong, governor of the People's Bank of China, at a dinner hosted by the Hong Kong General Chamber of Commerce, hinted at the 
possibility of banks in Hong Kong accepting renminbi deposits. This is in fact a relaxation of exchange controls between Hong Kong and mainland China and is perhaps the first step for full eventual convertibility of the renminbi. If so, banks in Hong Kong will be able to make renminbi loans. Although the idea is new and rather vague at this moment, banks should be prepared to explore the opportunities open to them once the idea becomes a reality ${ }^{13}$.

On another occasion Dai hinted that, in principle, there is no reason why mainlanders cannot invest in the Hong Kong stock market. They can invest through the Qualified Domestic Investment Institutions (QDII). The matter is currently under study by the central government. If this becomes a reality, not only will stock brokerage firms in Hong Kong benefit, the banks will also benefit from providing banking facilities for these financial transactions ${ }^{14}$.

According to the statistics released by the International Clearing Bank, in the three years from 1999 to 2001, China's reserves increased by US $\$ 1,424$ billion. However only about one tenth of this has been invested in Hong Kong. The majority is invested overseas in the form of Western government bonds. If China changes its policy and begins to increase its investment in Hong Kong, the first to benefit are the institutions in the financial sectors, including Hong Kong's banks ${ }^{15}$.

A new development is the introduction of the QDII by the mainland Chinese government. These QDII can act as trustees for foreign investors to invest in mainland stocks and securities. The Bank of China and a few other mainland banks have been granted QDII_status. The Hongkong \& Shanghai Banking Corporation, the Standard Chartered Bank and Citibank, all of which already operate in Hong Kong, have filed their applications to become QDII. It is expected that this development will open up yet another business opportunity for Hong Kong's banks ${ }^{16}$.

57 The Trade Development Council (TDC) is a government-related institution responsible for development of Hong Kong trade. According to a paper published by the TDC, financial institutions in Hong Kong can benefit from China's entry to the WTO. Hong Kong has always been the major source of foreign funds for Chinese enterprises. The sources include direct investment by Hong Kong companies, funds raised on the Hong Kong stock market through public listing, and loans by Hong Kong banks. The further opening of China's financial market following its WTO accession will create more opportunities for Hong Kong financial institutions to participate in the mainland market and will give Hong Kong a chance to strengthen its role as an international financial centre ${ }^{17}$.

58 According to another paper published by the TDC, Hong Kong banks have the advantage of participating in renminbi deposits business in mainland China. Hong Kong banks constitute a large foreign banking group in the mainland and will benefit from further relaxation of rules on foreign banks conducting business in renminbi. Business opportunities are enormous as $10 \%-20 \%$ of all renminbi deposits, totalling over 10,000 billion yuan, are expected to flow from local to foreign banks ${ }^{18}$.

Another paper published by the TDC points out that the financial industries of Hong Kong will benefit from four areas of infrastructure construction in mainland China, namely, infrastructure construction required as a result of WTO entry, the Peking 2008 Olympics, western inland region development plans and housing reform. Banks will play a role in the funding of these projects ${ }^{19}$. To these projects now must be added the 
2010 Shanghai World Expo projects which China has successfully bid for. These projects will open up further opportunities for Hong Kong's financial industry.

The way China's government looks at Hong Kong is perhaps most important in discussing the future role of Hong Kong. In a press conference held after the closing of the Ninth People's Congress, premier Zhu Rongji delivered the central government's optimistic view of Hong Kong's status as a regional financial centre as follows:

"I think Hong Kong has not lost its strength as Asia's financial centre. In future, as the world economy develops, I think there should be some adjustments to the role of Hong Kong. [...] I firmly believe the strong points of Hong Kong have not been fully utilised. There is no limit to its future role" ${ }^{20}$.

61 Premier Zhu did not explain the adjustments that Hong Kong should make. But it is obvious that, as China's economy experiences changes along with its entry into the WTO, the role of Hong Kong also has to change. In addition to being a financial centre supporting the economic development of China, Hong Kong should more actively explore business opportunities in China. In particular, Hong Kong with its connections with the outside world should be able to contribute by establishing business relations between China and the outside world ${ }^{21}$.

By 2004 foreign banks will be able to conduct renminbi business with Chinese enterprises in Shanghai, Shenzhen, Tianjin and Dalian. By 2007, they will be able to deal with all Chinese enterprises without any geographical restriction. At present quite a number Hong Kong banks already have branches in China. They include the Hongkong \& Shanghai Banking Corporation, the Standard Chartered Bank, the Bank of East Asia, Citibank, BNP Paribas (formerly Banque Nationale de Paris) and others. Foreign banks (including Hong Kong's banks) need to have US $\$ 20$ billion in assets before they can apply for a licence. Under current rules, a foreign bank can only have one branch and can set up one sub-office in the same district each year.

Foreign banks, including the Hong Kong banks, are not just competing with mainland Chinese banks, but also among themselves. Competition is in the following three areas: 1) Foreign banks, including the Hong Kong banks, used to provide services to foreign companies, including Hong Kong companies. Now they are keen to extend these services to mainland Chinese companies; 2) Foreign banks, including Hong Kong's banks, used to provide trade finance to their customers. Now they are keen to expand into credit card business, unit trusts, investment consultancy, fund management, etc; 3) Foreign banks, including the Hong Kong banks, used to bring their staff from overseas and Hong Kong to mainland China. Now they want to recruit local graduates and experts in China's financial and legal matters ${ }^{22}$.

Another way the foreign banks, including Hong Kong's banks, can increase their presence in the China market is to acquire associates by investing in the mainland banks. As an example, the Hongkong \& Shanghai Banking Corporation has invested in the Bank of Shanghai and now holds $8 \%$ of its shares. This action is beneficial to both the foreign bank and its associate. The foreign bank can entrust its associate with the renminbi business. At the same time the mainland bank can learn from its associate modern banking business. As another example, BNP of France and the China Industrial and Commercial Bank have jointly set up the Shanghai Paris National Bank ${ }^{23}$.

According to another paper published by the TDC, compared to mainland banks, Hong Kong's banks are more experienced in consumer banking, and are thus in an advantageous position to capture a significant share of the market. Although they are 
constrained by their small branch networks, they may be more successful in providing customised services to higher income customers ${ }^{24}$.

After the Asian financial crisis banks in Hong Kong have experienced hard times with reduced profits, stiff competition, and the need to improve their business operations. Competition became keener still following interest rate deregulation in 2001. The major impact on the banks of deregulation is that they can no longer rely heavily on lending as a major source of income. Banks will have to expand their business into noninterest-earning business such as insurance, stock brokerage, fund management, and personal banking services. This is a development which took place long ago in the banking sectors of most Western countries.

Now that China has gained entry into the WTO, opportunities are open for banks in Hong Kong to operate in China. Meanwhile Hong Kong will become more important as a financial centre supporting the economic development of China, especially that of the Pearl River Delta region. If renminbi exchange controls are gradually relaxed, banks in Hong Kong will be the first to benefit from the business arising in this area.

Banks in Hong Kong should be prepared for these changes. They must strengthen their organisational structure and improve their business operations. They must equip their staff with up-to-date knowledge and expertise in their financial services. They must adopt advanced technologies for service delivery. Most important, they must be alert to the opportunities open to them in the mainland market. Hong Kong's role as an international financial centre requires adjustments to be made to bring it in line following China's entry to the WTO. Banks in Hong Kong must do the same.

\section{NOTES}

1. Throughout this paper 'Hong Kong banks' refers to all banks operating in Hong Kong. These include the local Chinese banks, the mainland Chinese banks, and the foreign banks.

2. For a description of the operation of the linked rate system, see Joseph Yam, "The Hong Kong Dollar Link", Quarterly Bulletin, HKMA, May 1998, pp. 45-59

3. For a detailed description of the structure of the three-tier banking system, see Jao Y.C., "Monetary System and Banking Structure," in The Business Environment of Hong Kong, Ng Sek Hong \& Lethbridge, David (Eds.), Oxford, $3^{\text {rd }}$ Edition, 1995

4. Peter Y.W. Chiu, "Economic Integration between Hong Kong and Mainland China," China Perspectives, No. 40, March-April 2002, pp. 62-71

5. See David Carse, "The Way Forward for Banking Sector Reform", Quarterly Bulletin, HKMA, May 2001, pp. 73-77

6. "Banking Stability: Consumer Protection", Annual Report 2001, HKMA, p. 54 
7.Joseph Yam, "Competition and Consolidation: The Outlook for Hong Kong's Banking Sector", Quarterly Bulletin, HKMA, February 2000, pp. 59-64.

8. "Banking Stability: Electronic Banking and Risk Management", Annual Report 2001, HKMA, p. 54

9. "Jinguan jushou jijie tou suyin xingsheng 1.72 bei" (Complaints received by HKMA increased by 172\%), Xinbao (Hong Kong Economic Journal), May 31st 2002, p. 2.

10. Joseph Yam, "The WTO: China's Future and Hong Kong's Opportunity", Quarterly Bulletin, HKMA, November 2000, pp. 110-116. 11. Ibid.

12. Joseph Yam, “ Understanding Mainland Financial Reform," Hong Kong Government Press Release, May 17th 2001. http://www.info.gov.hk/hkma/eng/viewpt/ 20010517e.htm.

13. Joseph Yam, "Renminbi Deposits in Hong Kong," Hong Kong Government Press Release, March 7th 2001. http://www.info.gov.hk/hkma/ eng/viewpt/20020307e.htm

14. "Dai Xianglong: Neidi jumin waihuike touzi ganggu" (Mainland Chinese's foreign currency saving, according to Dai Xianglong, can be invested in Hong Kong stocks), Xinbao, March 12th 2002, p.1.

15. "Neidi waihuijin yi heng liuru bengang" (Only 10\% of Mainland China's reserve is invested in Hong Kong), Xingdao ribao (Singtao Daily), May 28th 2002, p. B3.

16. "Jiaoyinfu gang xingtui QDII fuwu" (The promotion of QFII by Bank of Communication in Singapore), Xingdao ribao, January 13th 2003, p. B3

17. "China's WTO Accession: Implications for Hong Kong as an International Business Centre", Economic Forum, Hong Kong Trade Development Council, September 2001. http://www.tdctrade.com/ econforum/tdc/010901.htm

18. "Executive Summary," Economic Forum, Hong Kong Trade Development Council, November 22nd 2001. http://www.tdctrade.com/ econforum/tdc/011101.htm

19. “China's WTO Accession: Bricking Up the Future - Infrastructure and Real Estate Opportunities for Hong Kong on the Chinese Mainland," Economic Forum, Hong Kong Trade Development Council, December 13th 2001. http://www.tdctrade.com/econforum/tdc/011201.htm. 20. "Zhu's upbeat vision for HK," South China Morning Post (Newspaper in English), March 16th 2002, p. 4.

21. Ibid.

22. "Zhongwai yinhang jingzheng san da jiaodian" (Chinese banks and foreign banks compete in three major areas), Xinbao, May 1st 2002, p.1.

23. Ibid.

24. "China's WTO Accession - On the Fast Track: Financial Services", Economic Forum, Hong Kong Trade Development Council, March 25th 2002. http://www.tdctrade.com/econforum/tdc/020301.htm 